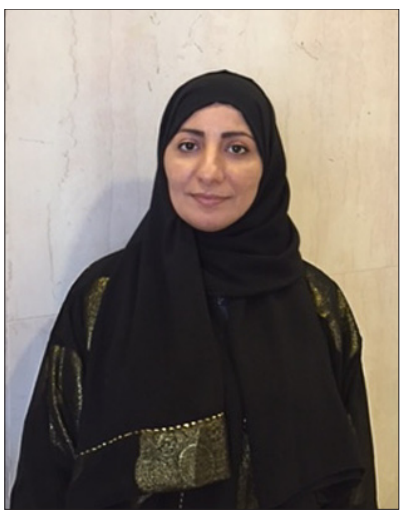

Talha FADAAK

Umm al-Qura University talhafadak@hotmail.com

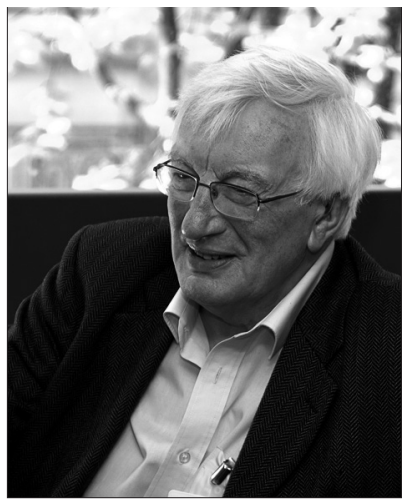

Ken ROBERTS

University of Liverpool bert@liverpool.ac.uk

УДК: 316.334.22:316.346.2-055.2+ 37.03

\title{
WOMEN, EDUCATION AND EMPLOYMENT IN SAUDI ARABIA: AN EXAMPLE OF MULTIPLE MODERNITIES
}

This paper uses official statistics and previous research by Saudi scholars, but mainly our own evidence from 23 interviews during 2015 and 2016 with 25-35 year old males and females, to explain why modernisation is Saudi Arabia, which includes the diversification of its economy and a huge expansion in higher education for males and females, is unlikely to lead to a higher proportion of women in the workforce. This is because the total number of jobs in the country is unlikely to increase, and opportunities for women are likely to remain limited not only by employers' hiring preferences and practices, but also by the limited range of jobs that young women and their families consider acceptable. Thus rather than following the same modernising path as Western societies, Saudi Arabia will add to the examples of multiple modernities.

Keywords: education, employment, gender, late development, modernisation, Saudi Arabia.

\section{Introduction}

Present-day Saudi Arabia is a serial paradox. It is simultaneously an absolute monarchy and key military ally and trading partner of Western democracies. It is probably the most conservative among all Islamic states - apostasy is a capital offence, and the only legal sex is between a married man and woman - yet enjoys living standards equal to Americans'. Its young people are among 
the world's most highly educated, yet the country has one of the world's lowest employment rates for men, and even more so for women. Mountains of 'investment in human capital', a favoured Western paradigm for the social role of education, appear wasted.

Here we focus on the co-existence of highly educated and mostly non-employed young women, and ask whether this appears puzzling only to an orientalist gaze which views the East using a Western mind-set (Said, 1995). Western societies pioneered, and Western social science has defined, modernity. The West is the source of the view that all countries are now joining the same historical track, the only serious opposition to the global, capitalist market economy having disappeared with the collapse of communist regimes (Fukuyama, 1992). The World Values Surveys are a product of Western social science. Their evidence suggests that, although history always leaves an imprint, the same value shifts are now occurring in all countries. These shifts are said to be away from respect for traditional authorities such as religious leaders and hereditary monarchs, and away from survival towards self-expression values which release individuals' aspirations from ascribed statuses such as sex and ethnicity, and not only tolerate but applaud the co-existence of multiple sexualities and lifestyles. These shifts are said to start among urban, highly educated young people, then spread outwards and among all age groups through cohort replacement (Dalton and Welzel, 2014; Inglehart, 1977, 1997; Welzel, 2013; Welzel et al, 2003).

Up to now Saudi Arabia has been able to purchase its apparently paradoxical status because during the $20^{\text {th }}$ century it became the world's ultimate oil state: it still holds around a quarter of the world's known oil and gas reserves. At one time, not long ago, oil and gas revenues accounted for over 90 percent of government income. During the latter part of the $20^{\text {th }}$ century these revenues enabled the regime to provide Saudis with modern education and health services, to build modern cities, and to employ Saudi males in secure government jobs on salaries that enabled their entire households to live a Saudi version of the American way of life. Demand for labour exceeded local male labour supply and the chosen solution was not to employ Saudi women but to fill most jobs with foreign labour. It remained unnecessary for Saudi women to enter the workforce except in niches such as teaching in girls-only schools. One salary was sufficient to support a Saudi household.

Today the Saudi regime knows that the country must change. The Saudi population has grown from around four million in 1960 to roughly 20 million today. It is still growing strongly because the typical Saudi woman gives birth to 2.9 children, well in excess of the population replacement rate. A half of the population is aged under 25 . The country needs somehow to employ all its own young males. The government can no longer afford to employ them all. This became a public issue even before the dip in global oil and gas prices during 
and after 2014, which has meant a steep decline in state revenues (Kingdom of Saudi Arabia, 2014; Kingdom of Saudi Arabia, Ministry of Economy and Planning, 2010). This is the context in which the regime now plans to transform the country into a more diverse, less oil and gas dependent, knowledge economy (Kingdom and Saudi Arabia, 2013), and since 2005 it has pursued a Saudisation policy, which means replacing foreigners with Saudi employees (Ministry of Labour, 2012). Accordingly, the government has funded a massive expansion of the country's education, spending around 10 percent of GDP on this, the world's highest figure (Ministry of Education, 2015). It has created a mass higher education system at home, and funded thousands of scholarships enabling Saudi students to study abroad. So far, these changes have not been the hoped-for catalysts for restructuring the economy or Saudising the workforce to anything like the extents deemed necessary. The Saudi government has a target of Saudising 75 per cent of private sector jobs, but many private sector employers currently struggle to meet the current requirement of 10 percent (Ministry of Labour, 2012). It might help to diversify the Saudi economy if more use was made of females' capabilities. This would also contribute massively to Saudisation. However, this assumes that young females acquire, or want to acquire, relevant capabilities. It also assumes that young females want to enter, or even would accept, jobs currently performed by foreigners and Saudi males. It assumes that private sector employers will be willing to replace their foreigners with Saudi females (or males).

The following passages discuss whether demographic trends and the Saudi government's current budgetary deficit will lead to the expansion of women's education (which has already taken place) being followed by a rise in their presence in the workforce, but before proceeding we must note that there is an alternative to the 'all on the same track' modernisation thesis. The alternative claims that we have entered an age of multiple modernities (Eisenstadt, 2000; Martinelli, 2007), all built selectively on countries' own traditions. Late-developing countries always differ from their predecessors in being able to leap from their former selves into hyper-modern versions of existing modern societies (Dore, 1973, 1976), or they might develop entirely new versions of modernity. Saudi Arabia will be an example if it retains its traditional gender order, but is this likely? The structure of the Saudi economy, and the composition of the workforce, must change in some ways. How likely is the gender order to be among these changes?

The following passages engage in, but do not seek to close, this debate, by asking, first, whether young Saudi females' low employment rates are due to women's currently limited employment opportunities or to their own agency. Official statistics on education, the economy and employment, are used to identify regular patterns of behaviour which need to be explained (Goldthor- 
pe, 2016). Thereafter we use published research mong young Saudi women by Saudi scholars, but mainly our fresh findings from 13 interviews with 25-35 year old females that were conducted in Jeddah and Mecca, two major cities in Saudi Arabia, in 2015 and 2016. Ten of the women were married, and their husbands were also interviewed. We occasionally refer to the husbands but most of our evidence is from the interviews with the young wives. The interviews focused on the young women's life stage transitions from education into employment or non-employment. Half of the married interviewees were selected on the basis that they were living in villas, which indicates that the households were part of Saudi Arabia's middle class, while the rest lived in traditional houses located older, traditional districts in the cities. As explained above, 10 of the female interviewees were married, and although they were not selected on this basis, none had ever sought employment. The other three young women were selected for interview deliberately because they were both single and employed. These numbers reflect the proportion of the age group's females who are active in Saudi Arabia's labour market today. Around a third of 25-29 year olds are 'active' in the labour market, of whom only two-thirds are actually employed (Ministry of Labour, 2015). The interviews allow the married and single young women to illustrate at the level of actual biographies, and in their own words, the meanings of the regular patterns that the statistics identify, and also enable us to identify the immediate causal mechanisms which explain the patterns. Causal mechanisms always and necessarily operate via individual agency: motivations, definitions of their situations, the options that they perceive, their evaluations of these options, then the choices that people make (Goldthorpe, 2016).

The next section sketches the context - education, the economy and employment in present-day Saudi Arabia. We then proceed with the evidence from our interviews. Finally we return to our larger question. Is the combination of a highly educated and mainly non-employed female population an obstacle and unsustainable? We shall argue that it is not only compatible but might even be an asset during the development of a late-arriving Saudi example of multiple modernities.

\section{Education, Economy and Employment in Saudi Arabia}

\section{Education}

The Saudi government began to provide public education in 1925 but schooling girls was actually prohibited until 1960 . Since then progress has been rapid. Even today no schooling is compulsory, but Saudi Arabia has built a modern education system (Ministry of Education, 2015). Structurally the system is like America's: six years of elementary education, followed by three 
years of intermediate, and a further three years to complete a full secondary education. All education is sex-segregated. After secondary school students can progress to a university or they can study for a technical or some other vocational diploma. The Saudi government hopes to increase the numbers who take vocational options but take-up has been low. Students who continue beyond secondary school almost always aim for university. All state education is free and maintenance allowances are paid to university students. Private fee-paying schools operate alongside the state system, but those that educate Saudis must follow the nationally prescribed curriculum.

Among 30-34 year olds in 2014, that is, those born in the early-1980s, a cohort from which the young adults who we interviewed in 2015 and 2016 were drawn, a few had remained illiterate and others could just read and write. They would have lived in the desert and small villages rather than cities such as Jeddah and Mecca from where our interviewees were drawn. However, from the early-1980s birth cohort, 79 percent of boys and 80 percent of girls at least completed intermediate school at age 15/16. Girls had made spectacular progress since 1960: 31 percent from the early-1980s birth cohort achieved a BA or a higher academic qualification. Among males it was just 21 percent (Ministry of Labour, 2015).

There has been considerable change since the birth cohorts of the early1980s progressed through education. In 2013 two-thirds of 18 year old males and females commenced university (Observatory on Higher Education, 2014). This implies a doubling of the participation rate among females and tripling among males over the previous 20 years. This rate of expansion has been remarkable, possibly unprecedented anywhere in the world, and accounts for the exceptionally high proportion of GDP (10 percent) that Saudi Arabia was spending on education by 2013. The expansion of higher education has been at the forefront of government efforts to create a diversified knowledge economy in Saudi Arabia. In quantitative terms, the government's drive to produce more knowledge-laden young people must be judged a success. A shortage of highlyqualified labour must have ceased to be an obstacle to the development of a knowledge economy (if it ever was). Present-day Saudi Arabia has an abundance of university graduates. Many have received all (or more frequently part of) their higher education abroad.

\section{Economy and employment}

Saudi Arabia is often called an oil economy. This is accurate in so far as oil and gas account for 55 percent of GDP and at one time accounted for over 90 percent of government revenue but by 2015 this had fallen to 73 percent (Kingdom of Saudi Arabia, Ministry of Finance, 2015). Up to now the Saudi state has run on fossil fuels. However, the oil and gas industries do not loom large 
in the lives of most Saudis except that consumers are now having pay more for these products because government subsidies are being cut. The oil and gas fields are clustered in the north-east of the country. Only five percent of all Saudi employees work in oil, gas or any other kind of engineering, manufacturing or extractive industry. Only one percent of employees in the oil and gas fields are Saudis (Ministry of Labour, 2012, 2015).

However, many Saudi lives are funded by oil and gas: specifically the working lives among the 1,240,748 who were directly employed in government departments or state services in 2015 (Kingdom of Saudi Arabia, Ministry of Finance, 2015). Less than six percent of government employees are foreigners. Government jobs are usually reserved for Saudis. Most of the exceptions are in health care (over 50,000) and there are over 16,000 foreign university staff. These foreigners are either skilled specialists, typically from other Middle-East countries, or ancillary staff (cleaners, porters, kitchen staff, shop assistants and suchlike) who are usually recruited from the Far East.

The Saudi government publishes salary scales for all types of government jobs. In government administration there are 15 grades, on each of which staff receive annual pay increments for up to 16 years. Salaries on the lowest administrative grade start at $\$ 800$ a month and rise to $\$ 1304$ for anyone who remains on the bottom grade for 15 years. The minimum pay for any Saudi, whether in public or private sector employment, is supposed to be $\$ 800$ a month. If an individual doing administrative work in a government department is promoted to a middle grade, say grade eight, the monthly salary eventually rises to $\$ 3685$. The highest monthly salary on the administrative scales is $\$ 7637$. There are 25 grades in school-teaching. The lowliest teaching assistant earns $\$ 1185$ and the highest pay available in a classroom is $\$ 4596$. A university lecturer can earn up to $\$ 4241$ and a top professor can earn a maximum of $\$ 7053$. A consultant doctor's monthly pay can be as high as $\$ 10,411$. These are eye-catching sums, especially since the incomes are tax-free. Also, government jobs are secure, redundancies are unknown, and staff retire on generous pensions. The salaries are vastly superior to earnings in other Middle-East states except the smaller Gulf States which also run on oil and gas. Saudi salaries tempt European and North American professionals. Foreigners are on contracts of finite duration and do not accrue pension or any other state welfare entitlements. They need to purchase their own health insurance and pension plans. They are a flexible fringe to Saudi Arabia's professional workforce.

The Saudi government employed 1,170,000 Saudis in 2015, and they have been an 'aristocracy' of the labour force, albeit a steeply tiered aristocracy. As seen above, salaries start from $\$ 800$ a month but a university graduate would not expect to start on less than $\$ 2000$ and to achieve pay rises to no less than $\$ 4000$. These are attractive salaries but are received by only just over a million 
Saudis. Most of these are men who have short working lives (by present-day international standards) starting in their mid-20s and ending during their 50s. The salaries will have to support a wife, children, possibly older relatives, a housemaid, a driver for the family's second car and a villa to accommodate everyone. This is $a$ Saudi way of life to which some young people, mainly university graduates, but also others who have known this life as children, are likely to aspire.

There is another Saudi Arabia. The country's private sector accounts for only around 40 percent of GDP but has a far larger workforce than the public sector. Foreigners comprise approximately a third of the country's total population and 55 percent of the official workforce. Saudis are estimated to account for no more than 10 percent of private sector employees but this ignores those undertaking informal paid work. Private sector pay is up to the employer. There is no minimum for foreigners. Saudi Arabia has a small number of large conglomerates (parent companies which own or partly-own numerous smaller companies which may operate in many business sectors). The conglomerates are always mainly or wholly Saudi-owned. Foreign investment in Saudi Arabia has been permitted since the mid-1980s, and wholly foreign-owned enterprises have been permitted since 2000 , but the country is hazardous commercial territory. There are 'commercial norms' but no commercial law in the sense understood throughout most of the world. The safe way of doing business is with royal patronage, and most conglomerates were created specifically to execute state contracts.

Saudi Aramco is the world's most valuable business. It is 100 percent state owned and employs around 60,000 but few of these are Saudis and none are counted as government employees. Sabic is a large private company that was founded by royal decree in 1976 to supply and trade in chemicals, fertilisers and metals, and this private company is still 70 percent state-owned. The Binladin Group was founded by the father of Osama Bin Laden in 1931 and specialises in construction projects which in Saudi Arabia have typically been state-funded, but the group now operates throughout the Middle-East.

Most foreign workers in Saudi Arabia are housemaids and drivers, the workers who actually construct Binladin projects and supply the 'labour' that makes Saudi Aramco and other private businesses work. Foreigners are preferred whenever long-term loyalty is unnecessary (though foreigners' contracts can be renewed) because they are usually much cheaper than Saudis who normally expect, but nowadays may not receive, salaries comparable to those in the state sector. Most Saudis who earn the whole or part of their livelihoods privately are not in the 10 percent officially counted as part of the private sector workforce. They include farmers, market traders, car repairers, and those who use their 
own cars as taxis. These are part of a substantial informal sector that exists across the whole of the Middle-East and North Africa.

Reliance on foreign labour is no longer due to a shortage of Saudis in the normal working age groups. Rather, it is because the country has an unusually low rate of labour force participation, especially by women, combined with a high rate of female unemployment. Ninety-two percent of Saudi males aged 25-29 are economically active. Up to now the Saudi government has ensured that they have employment by creating jobs in government departments. However, by age 55-59 male workforce participation has declined to 67 percent. Men are allowed to retire early from government jobs, on generous pensions. Jobs are vacated for younger men. There is considerable over-staffing in government departments. Female labour force participation rates are much lower: just 33 percent in 2014 among those aged 25-29 when most are housewives, mothers or simply helping at home. By age 55-59 just one percent of Saudi women are economically active (Ministry of Labour, 2015).

Unemployment in Saudi Arabia is measured in the internationally standardised way in a Labour Force Survey (Ministry of Labour, 2015). In 2014 the male unemployment rate was 5.8 percent. The Saudi government will do everything possible to ensure that men can obtain jobs, earn salaries and be providers for the households which they will normally head. The labour market situation is different for young, 25-29 year old, Saudi women. In 2014 their official unemployment rate was a massive 32.8 percent (Ministry of Labour, 2015). This means that a third of the minority who were actively attempting to participate in the workforce were unemployed. There are few jobs for which women can apply. Saudi culture requires the sexes normally to be segregated at work. So there are jobs for Saudi women as teachers, and also in health care and social services (all in the state sector) as well as in some government offices. There is a further impediment facing women job-seekers. Women are not allowed to drive in Saudi Arabia. There is usually no useful public transport. So to hold a job a woman usually needs the use of a car and a (male) driver or to be able to afford taxis.

The difficulties faced by young would-be female employees have been the subject of several investigations. Almoneim (2009) studied unemployment among Saudi graduate women. The study noted the higher rate of unemployment among Saudi females compared with Saudi males, and concluded (only and disappointingly) that this needed more investigation to find effective solutions. Local researchers have identified a series of impediments to young male and female Saudis seeking and obtaining jobs in large- and medium-sized private sector companies. The Research and Consulting Institution (RACI) in King Abdulaziz University conducted research into the reasons for the reluctance for young people to work in the private sector. This research questioned 
5,102 males and females aged 15-35 from all educational levels, employed, inactive and unemployed. Their reasons for reluctance to work in the private sector were: the places were too far away, no work for females, no separate environment for females, and above all else, the public sector was simply better - the jobs had higher status, paid better salaries and pensions, and there was tough competition from (cheaper and easier to discipline) foreign workers in private firms (Research and Consulting Institution - RACI, 2010).

Government efforts to oblige private sector businesses to employ Saudis have had very limited success. Government jobs are preferred by Saudis on account of the higher status, security, salaries and pensions, and less exacting employment regimes. Even Saudi nationals who are private sector employers may prefer to hire foreigners who are better-motivated and who need to be compliant. Unless private sector employers have at least 10 percent of Saudis on their payrolls they can be refused authorisation to hire more from abroad or to renew existing foreign employees' contracts. The government has hesitated at raising the 10 percent threshold because it knows, first, that this would increase businesses' payroll costs, and second, there would be a shortage of Saudi applicants for the jobs.

These are the labour markets that await young Saudi males and females on completing their education, nowadays mostly with university degrees.

\section{Women and Employment}

It is easy to use our interview findings to show that many (probably most) young Saudi females remain economically inactive because they never entertain any intention of seeking paid employment. It is equally easy for us to show that women's employment opportunities are confined to a small number of gender-segregated niches. It is equally easy and correct to argue, as we will, that women's limited interest in employment is a response to their limited opportunities, and equally that employers create few gender segregated female niches because few Saudi women would seek to fill them. Our task is not to allocate proportions of responsibility to labour supply and demand, or just to illustrate their interaction, but to anticipate likely outcomes in a Saudi context, and the plausibility of the country being able to preserve the gender status quo in its own version of a modern society.

\section{Don't want to work}

None of the 10 married women who we interviewed had ever tried to find employment. It made no difference whether or not they had been to university. They had all completed their education then 'waited for the right man' who would be identified by their mothers or fathers, or possibly by a sibling. All 
marriages in Saudi Araba must be arranged, at least in the sense that they must be authorised by the bride's guardian, usually her father. In any case, there are very few, if any, opportunities for young single males and females to socialise outside their family homes.

Nouhra, one of our married interviewees, was from a villa family as was Omar, her husband. There had been an expectation in both families that Omar and Nouhra would go to university. A difference was that while Omar had been guided by his father, first to take a BA in business studies, then an MA in finance, which had led to his employment in the stockbroking section of a bank, in Nouhra's case her progression to university was not with a subsequent career in mind. 'I lived in a good family. I saw how my father treated my mum so my dream was to get a husband similar to my father. He had a good business so we had a housemaid and driver. I did not like studying but I had to get a BA so I tried my best to graduate from the biology faculty and managed a grade $\mathrm{C}$. After that I stayed at home waiting my dream man. That man came quickly.'

Jude and Ali, another married couple, were also both from villa families, but Ali had been guided by his father to study medicine which had led to his current employment as a hospital doctor, whereas Jude's education had not been with medicine or with any other career in mind. She explained that, 'I lived with my family. I was a good student but I did not have a specific subject to study. I selected English language because I liked English movies so I found it easy to graduate from university with a degree in English.' Jude's family had expected her to go to university, but like Nouhra, this had not been to prepare for an employment career.

Why do young women go to university if they have no intention of ever entering employment? Why do their families expect this? It is partly because university is a good place to 'wait'. It enables young women to go out daily and socialise with female friends. It also enhances their value as future brides. Saudi families expect their sons and daughters to marry social equals. In traditional groups this may mean marrying within the extended family or within a tribe. In modern Saudi families (the middle classes who typically live in villas) it means finding a bride or groom from a similar modern family, with a similar modern outlook, with a similar level of education and a family with similar financial resources. Males will not marry until they have established themselves in jobs with salaries that enable them to act as family providers. They or their families will need to provide the new couple with a place to live, and they will also need to pay a dowry and for the wedding celebrations. So male graduates are unlikely to become 'available' until they are in the late-20s or early-30s, and although grooms tend to be several years older than their brides, this means a long wait for girls who finish their education at age 16 or 18 if they want graduate husbands with graduate jobs and salaries. 
Samah had experienced a long wait. When interviewed she was married to Fahad who had studied marketing at university and had since become a sales director in a well-known private sector company. Samah was from a similar villa family. She spoke as follows. 'I lived in my family among four brothers. My parents loved me a lot because I was their only daughter. I was in a private school. I was a normal student but I was not planning to go to university. I liked to read and listen to music and I told my father one day that I would like to study music. He just laughed and said you can listen to it and dance and that's enough. When I finished secondary school I did not want to go the university. So I spent my time playing around, reading, listening to music and traveling with my family.' Then Samah's parents had received a proposal from Fahad's family. Samah had been educated at a private school, but had been under no family pressure and had no interest in progressing further in education or preparing for a career.

None of the non-graduate women had ever sought employment. They had all married local men, often relatives, soon after completing their education. All but two of the husbands had government jobs. There are few public or private sector jobs for which non-graduate women might apply. One non-graduate wife was earning some income by practising henna - inscriptions on the arms and hands of girls and women, but her husband insisted that this work be confined to weekends. During the week she was expected to care for her home and children.

\section{Opposition from husbands}

Young Saudi women who want employment careers know that they are likely to face opposition from husbands who feel that it is their job to be, and want publicly to be seen to be, the family providers.

Haila's ambitions had been frustrated in this way. She had married Saad, a policeman. 'He rented a traditional house. That was not my dream but we have to live according to our budget. Saad's salary is not quite enough for our life. I have a BA in social work so I hoped to find a job but Saad did not like the sound of this. First, he does not want people saying that I work to support him. Second, he does not want me to go with a driver alone and he will not be able to take me to work in the light of his own job. We need to increase our income. The cost of living is high. We live on the border financially. I need more clothes, shoes, makeup and perfumes. Our bills increase. I need clothes and gifts for visiting my friends, and gifts for my family in Eid and Ramadan. We need to go for short breaks to places like Dubai. My university friends go and most Saudis now go there. It is not expensive but still we cannot afford it. I think finding a job for me is very important at least to cover my requirements without putting 
a load on him. I wish his salary could get better, if we could get a good house, and if I could get a good paying job.'

Jaber and Marem, another married couple, had a housing problem. Jaber, who was employed in an administrative job in a government department, saw the problem as follows. 'My wife owned a traditional house (inherited from her father) so her mum suggested that we should live there. I accepted and paid $\$ 500$ per month to my wife as rent. This was important because I was responsible for the cost of living of my wife and I had to protect my social appearance as a Bedouin man. I now pay her just $\$ 270$ monthly. The house needs maintenance all the time and this costs me a lot of money. So my plan is not to stay in a traditional house. It is to buy an apartment, but how? My salary is low compared with the cost of living.'

Marem could see a solution that would not involve waiting, but could not persuade her husband. 'Everything is fine but still we have our problem with house maintenance so my husband will see if we can get another house that will be better. I told him that I will give him my savings and he can get a bank loan but he has refused for two reasons. The first is that he doesn't want to touch his wife's money.' Saudi males feel that they must be, and be seen to be, their families' providers.

\section{The employers' perspectives}

The experiences of two of the unmarried 25-35 year old women who had built occupational careers of eight and ten years duration respectively illustrate why Saudi employers will tend to hesitate before employing women, and also why employers will resist government exhortation to Saudise their workforces irrespective of gender.

Fatima was a nurse with eight years experience who had risen from novice to senior nurse in a public hospital. Fatima appeared to have always been determined to make herself financially independent, which could have been due to her experiences during and following her parents' divorce. She explained that, 'The real problems which Saudi nurses face are the social and cultural factors that surround their work. These discourage nurses from developing their skills and getting ahead professionally. Let me tell you some examples. During our studies, we (I mean the Saudi nurses) did not have enough opportunities for practising to gain experience. After graduation we were supposed to work in the public or private sectors as 'nurses under training'. Unfortunately most of us did not benefit from that period for many reasons. One reason was the long working hours: 12 hours daily in two shifts. This did not suit the Saudi girls so some asked to work just one shift (six hours) or organise their work into three or four days then take a break for the rest of the week. Some girls refused to work nights, and some also refused to work with male patients: they did not 
want to touch the bodies of males. Saudi nurses are restricted by their families' rules and also by the conservative culture so they do not like staying for a long time outside their homes. This issue is very difficult while working as a nurse because this requires us to work long hours during the day and night. All these factors push the hospital administration to transfer Saudi nurses to administrative work. Also, sometimes they have been put into specific departments such as women's or children's wards to deal with females and children only, at their request. All these things hinder the professional development of Saudi nurses on the one side.' Fatima's hospital preferred to employ Filipino nurses. They were better-skilled, willing to work the required hours, to deal with male and female patients, and were paid less than Saudis.

Eman and Reem, the other two unmarried female employees who were interviewed, might have stumbled into their careers only because they received no marriage proposals soon after completing their education. Eman had taught herself make up and hairstyling at home, practising on herself and her mother. Her work had been admired by relatives and family friends, who asked Eman to do their hair and make up, which before long led to Eman being invited by an aunt to work in her beauty centre (hair, nail and skin treatments, and a spa facility, all for female clients only). When interviewed Eman was managing the centre having worked there for 10 years. She had left school at age 16 (she had not enjoyed studying). Eman explained that, 'It has taken many years to reach my current position. After two years my aunt transferred me to be the main cashier. Later I became the supervisor for all financial issues and now I am the manager of the entire centre. The centre has 22 beautician employees and four servants so the total is 26 . Four administrative jobs are for Saudi women. Their families would disapprove if they did any other jobs. They insist on their jobs being described as "clerk" or "administrator". Then we have four hairdressers who are Lebanese, Syrian and Ethiopian. There are two manicure specialists for nails: they are Filipinos. The four spa and massage specialists are Moroccans. The four specialists for makeup are Lebanese except just one Saudi girl. The two kitchen servants are Filipinos, and the two cleaners are Indonesians. The basic salary for Saudi girls is $\$ 1066$. I am different: my monthly salary is $\$ 1333$. The other foreign staff, hairdressers and other specialists, earn between $\$ 800$ and $\$ 1066$. The servants (kitchen staff and cleaner) are paid \$533.'

\section{Limited opportunities}

Gender segregation is not enforced rigidly. There can be exceptions 'when necessary' as in medicine and when television newscasters are female. Employers will justify employing women in gender-mixed environments when the women can offer scarce skills. Fahad, who had been educated privately and had become a sales director in a private business had two younger sisters who 
had also been educated privately and were currently studying ICT at university. They were likely to find jobs, if they wished, in either the private or public sector. Unless they can offer skills that make them superior to male job-seekers, Saudi women will find it difficult to find private businesses that are willing to risk employing both sexes. Any Saudi will be paid more than a foreign equivalent and there are additional costs when Saudi women are involved. Eman's experience at the beauty centre was that the presence of Saudi women in a workforce attracted repeated visits from the religious police who were concerned about the enforcement of dress codes, that there was no inappropriate literature, and that a room was set aside for prayer. Saudis are not obliged to pray five times a day or attend mosque on Fridays, but employers are expected to consent and facilitate if any Saudi employee wishes to do so. Fatima's hospital 'had' to accommodate Saudi nurses who did not want to work nights or even to be away from home after dark. It is easy to understand why private businesses will prefer Filipinos, Indonesians, Moroccans - anyone but Saudis.

So women job-seekers try to enter a limited number of public sector occupations where there are places for females. Teaching is favoured by university graduates like Reem, a Saudi Bukhari, a Moslem group that had migrated from Central Asia following the Bolshevik Revolution in Russia, and had settled mainly in the Mecca region. Reem had graduated from university with A+ in English studies. Her subsequent experiences illustrate the difficulties that face young women who seek employment in the one unequivocally socially acceptable profession for women, namely teaching. 'After graduating I applied online to the Ministry of Social Service for an education job but unfortunately the priority was to have an education background. I had graduated from an academic department so I had to take another course which was the Diploma of Education. I applied and was accepted but unfortunately I had to pay for this course. It had been free two years previously but the rules had changed. The cost for the three terms was $\$ 2400$. I had to study for one year then practise for three months in a public school. By then I was 24 years old. I applied for an education job according to the conditions of the Ministry of Civil Service. I filled in the online application then attached all the required documents and listed my preferred regions to work in. I put my preferred cities in order as Mecca; Jeddah and Taif. The result appeared few months later which was the offer of a job as an English teacher in a secondary school in Taif City.' This was too far for Reem to travel daily, and no male relative was able to accompany her to live in Taif and act as her guardian. Eventually Reem had arranged to share an apartment with two other female teachers at the school where she was employed. All were in the same situation of needing to live away from their families. Their male guardians jointly held the tenancy of the apartment and insisted that the 
teachers should receive no visitors, male or female. For six years Reem had been applying unsuccessfully for a transfer back to Mecca.

Jaber, the male graduate in Arabic languages who had married Haila, had experienced similar difficulties to Reem, but had a wider range of solutions. 'I graduated then I applied to the Ministry of Civil Service for a teaching job or any job in the public education sector. I did not receive any answer or comment and applied again after six months and went to their main office in Jeddah. Unfortunately they did not accept my application because a new condition was to follow my BA with another qualification which was the Diploma in Education. This would take two years of studying education modules with training in some schools. I was shocked because I could not return to study. Also, even if I would have liked to, a problem would have been the high competition and it would not have been easy to find a place on a course quickly. Third thing (he laughs), if I found a place on a course and spent two years completing it, there is no guarantee that I would get a teaching job. Perhaps they would change the conditions again. Oh my God. It was a very bad feeling. It took a long time until I applied again for any job suitable for someone with my qualification. I did not find such a job but there were administrative jobs, so I applied and got a job but beneath my educational level. No problem. I agreed because I wanted a job at that time. The rank of my job may be changed. I started six years ago in this administrative job in the Ministry of Culture and Information. My starting salary was $\$ 1,067$ whereas as a graduate I should have earned at least $\$ 1,600$ and now even after six years I have a basic monthly salary of just $\$ 2,133$.'

\section{Education and employability}

Local Saudi researchers have argued that at present higher education for women is not suited to the requirements of the labour market (for example, Al-Hamid and Jamhoom, 2009; Almoniem, 2009). They focus on the many female graduates who (like Reem) currently seek work as teachers. The supply of young women with this career goal is said to be overloading the occupation. There were plenty of teaching jobs for female graduates throughout the decades when female education was expending at all levels, and lastly in university studies, but this era has now ended. Education is fully staffed. Hence, Saudi researchers argue, higher education needs to be restructured while enlarging and reforming other sectors of the labour market so that they can accommodate Saudi females. However, Fatima's and Eman's experiences suggest that young women are highly restricted not only in alternative occupations where they will be accepted, but also which they and their families will consider acceptable.

Research among female university students finds large proportions saying that they expect to build employment careers. They insist that they are unlike their mothers: better educated (which is true), more likely to have employment 
careers (which is possible), and to share housework and child care with their husbands as well as housemaids (see Alfaqieh, 2012; Al-hmyari, 1991). However, these young women are likely to be over-estimating the range of occupations for which they might apply, under-estimating the competition that they will face, and the likely years of delay before they will be able to marry.

All three unmarried women who were interviewed hoped and expected to marry before long. They did not want to be lifelong spinsters. All three agreed that marriage was 'necessary' for a Saudi woman. All three had all already received offers which had subsequently been rejected or withdrawn. Reem and Fatima felt that their ability to contribute to household budgets should enhance their appeal as prospective brides, but the views expressed by the husbands of our married female interviewees suggest that Fatima and Reem could prove mistaken.

It is not only female graduates, but all graduates, who are now having difficulty in finding jobs. In 2015 Saudi Arabia's Ministry of Labour found that higher education graduates comprised 34 percent of the country's workforce but 51 percent of the unemployed. Saudi Arabia's higher education graduates today have a higher unemployment rate than any other educational group, a likely outcome from the recent expansion in student numbers (Ministry of Labour, 2015). The outcome has not been the formation or expansion of a highskilled, high value-adding labour force performing knowledge jobs but more unemployed and under-employed graduates. Most Saudi graduates who are in employment are not doing 'knowledge jobs'. The percentage working as directors, managers, in legal and other professions ( 45 percent) is exceeded by those doing technician, clerical, sales and other service sector jobs (55 percent). The Saudi government wishes to increase the number of young people who study for vocational diplomas but, whatever the intention, at present these courses do not lead to careers in oil and gas, construction, engineering and other types of manufacturing. The most common destinations of diploma holders are as technicians ( 48 percent) and clerks ( 25 percent).

Local researchers are invariably critics of what Saudi Arabia's schools are currently achieving. They find that students complain of heavy and difficult curricula, and the absence of activities for them to take part in, unsuitable school facilities, poor laboratories, sports halls and classrooms. Teachers also criticise the curriculum and say that it is not appropriate and needs updating. (King Abdulaziz Centre for National Dialogue, 2007). There have been calls for education and public policy more generally to support entrepreneurialism among Saudi students. Running a business is seen as a desirable career goal by many students, men and women alike, yet neither education and training nor public policy more generally are said to promote entrepreneurial skills and spirit among Saudi youth (Almobaireek and Manolova, 2012). 
Overseas experts add further criticisms. Some argue that there is an excessive emphasis on religious instruction throughout Saudi Arabia's education. In elementary school nine periods a week are devoted to religious studies and just 12 in total for maths, science, geography, history, physical education (for boys only) and domestic science (for girls). Religion is a compulsory subject at all levels, including university. A second charge from overseas is that Saudi education emphasises rote learning. Even university examinations require students to have learnt and memorised answers to factual questions. According to Chaaban (2008), there are heavy long-term costs. Saudi graduates are said to lack the ability to think independently and critically, and to find their own solutions to problems (see also Saleh-Isfahani and Dhillon, 2008).

\section{Conclusions}

The eye-catching salaries in government jobs and the de facto Saudi version of a youth guarantee - a government job for every Saudi male - were not too good to be true. The prospect of graduating university into an adulthood in a spacious modern villa with servants was not a mirage. However, it is all proving too good to last. It all became possible during the boom in oil prices during and following the 1970s. Up to then the country's population was much smaller than today's 30 million - just four million in 1960. As oil and gas revenues boomed it was possible to expand the economy by importing labour. The country could afford to do this. It was unnecessary to involve Saudi women except in certain niches. However, as the state took-on new responsibilities, their management needed the labour of the country's own growing male Saudi population. Saudi men occupied command posts. The staffed government departments and senior positions in major private businesses. These businesses used government money to build new cities and modern housing, and the government provided all Saudi citizens with free education and health care. The rulers spread their riches through these public services, and by providing Saudi males with well-paid jobs and the benefits of cheap foreign labour.

Ideally Saudi Arabia's knowledge economy will be formed by private businesses creating high-skilled, high value-added, high salary jobs that are filled by Saudis. The Saudi government is providing the highly qualified labour with two-thirds of its young people now entering higher education. Jobs which attract and satisfy these Saudis are proving more difficult to create. A 'bottom line' in economic planning has to be that the government now needs to curb its own spending. Public sector employment cannot continue to expand. The contributions of the global depression that followed the financial crash of 2007-2009 and the global search for a greener future can be debated, but an effect has been a slump in oil and gas prices on world markets which has left 
the Saudi government with a glaring budget deficit. Saudi government planning now takes into account a worst case scenario in which oil prices remain depressed throughout the 2020s. A response, familiar throughout the world, has been to cap public sector payrolls and to start to outsource the delivery of public services which means lower salaries, with Saudis sometimes competing with foreigners for jobs in private sector companies.

Overseas economists (for example, Morikawa, 2015) are fond of calculating the substantial amounts by which GDPs in North Africa and Middle-East states would rise if women's abilities were fully used, but even if all socio-cultural barriers were removed in Saudi Arabia (husbands' opposition, gender segregation and the ban on women driving), as in all other countries in the region there will be the challenge of creating additional jobs. The number of Saudi women seeking employment is likely to rise for three reasons. First, like school and university, employment offers a social life outside the home, and the longer they stay in education the greater will be young women's reluctance to withdraw into domesticity. Second, earning their own money leads to women's greater financial independence at home. Third, more and more couples will find that a villa and servants lifestyle requires more than one income. However, more good jobs for Saudi women will mean fewer such jobs for Saudi men.

Our prediction is that a main effect of Saudi Arabia's new economic circumstances will not be a general increase in female employment (making better use of this investment in human capital) but clearer class divisions. The traditional gender order will not be one of the weaker links that breaks in Saudi Arabia's new economic times. The first clearer division will separate an upper middle class that will be able to maintain Saudi traditions and its version of Islamic culture in households that can be supported by one male earner, but many of the wives will also be employed thereby boosting the families' standards of living, giving access to private schooling and health care as government spending on these services is capped and quality deteriorates. Other divisions will define a lower middle class in which the typical family will really need two earners in order to live in the way that its members feel has become customary for people such as themselves, but may have to depend on just one male salary. Finally there will be a lower class whose real net incomes will decline and converge with the incomes of the foreign labour that will continue to assist the middle classes in maintaining their current levels of consumption and standards of living. This will be Saudi Arabia's contribution to a global panorama of multiple modernities. 


\section{References:}

1. Alfaqieh H M (2012), The Impact of Urbanization on the Structure of the Saudi Family, National Centre for Social and Development Studies, Riyadh, No 102 (in Arabic).

2. Al-Hamid M and Jamhoom F (2009). 'Higher education for girls in Saudi Arabia and its relevance to the labor market', in Towards an Arab Higher Education Space: International Challenge and Social Responsibilities. Proceedings of Arab Region Conference on Higher Education, Cairo, 1-2 June (in Arabic).

3. Al-hmyari A A (1991), Cultural Communication and Changing Roles in the Saudi Family, Master thesis, King Abdul-Aziz University, Jeddah (in Arabic).

4. Almobaireek W N and Manolova T S (2012), 'Who wants to be entrepreneur? Entrepreneurial intentions among Saudi university students'. African Journal of Business Management, 6 (11), 4029-4040.

5. Almoniem S M (2009), 'Unemployment among Saudi graduate women', paper presented at Conference on Gulf Economic Integration, Saudi Economic Association, Meeting 17, 26-28 May 2009, Riyadh.

6. Chaaban J (2008), The Costs of Youth Exclusion in the Middle East, Working Paper 7, Middle East Youth Initiative, Wolfensohn Center for Development, Dubai.

7. Dalton R and Welzel C, eds (2014), The Civic Culture Transformed: From Allegiant to Assertive Citizens, Cambridge University Press, New York.

8. Dore R (1973), British Factory-Japanese Factory, Allen and Unwin, London.

9. Dore R (1976), The Diploma Disease, Allen and Unwin, London.

10. Eisenstadt S N (2000), 'Multiple modernities', Daedalus, 129, 1-29.

11. Fukuyama F (1992), The End of History and the Last Man, Penguin, London.

12. Goldthorpe J H (2016), Sociology as a Population Science, Cambridge University Press, Cambridge.

13. Inglehart R (1977), The Silent Revolution, Princeton University Press, New Jersey.

14. Inglehart R (1997), Modernization and Postmodernization, Princeton University Press, New Jersey.

15. King Abdulaziz Centre for National Dialogue (KACND) (2007), General Education Issues: Exploratory Study, KACND, Riyadh (in Arabic).

16. Kingdom of Saudi Arabia (2013), Transformation of the Kingdom into Knowledge Society/ Knowledge-Based Economy. Government of Saudi Arabia, Riyadh.

17. Kingdom of Saudi Arabia (2014), Objectives of the Tenth development Plan (2015-2019), Government of Saudi Arabia, Riyadh.

18. Kingdom of Saudi Arabia, Ministry of Economy and Planning (2010), The Ninth Development Plan, 2010-2014, Ministry of Economy and Planning, Riyadh.

19. Kingdom of Saudi Arabia, Ministry of Finance (2015), Recent Economic Developments and Highlights of Fiscal Years 1436/1437 (2015) and 1437-1438 (2016), Press Release, Riyadh, 28 December.

20. Martinelli A (2007), Transatlantic Divide: Comparing the United States and the European Union, Oxford University Press, Oxford.

21. Ministry of Education (2015), Education History in Saudi (Online). Available from https://www.moe.gov.sa/Arabic/Ministry/Pages/MinistryStart.aspx. Accessed 6 August 2015.

22. Ministry of Labour (2012). The Labour Market in the Kingdom of Saudi Arabia (Online), Ministry of Labour, Available from: http://mol.gov.sa. Accessed: 13 August 2015. 
23. Ministry of Labour (2015), Labour Force Survey 2014 - Round 2 (Online). Available from: file://C:/Users/toshiba/Downloads/manpower201402.pdf. Accessed 29 June 2015.

24. Morikawa Y (2015), The Opportunities and Challenges for Female Labor Force Participation in Morocco, Global Economy and Development Working Paper 86, Brookings Institution, Washington DC.

25. Observatory on Higher Education (2014), Higher Education in the Kingdom of Saudi Arabia: National Indicators and International Comparisons, Ministry of Higher Education, Riyadh.

26. Research and Consulting Institution (RACI) (2010), The Reluctance of Young People to Work in the Private Sector, King Abdulaziz University, Jeddah (in Arabic).

27. Said E W (1995), Orientalism, Penguin, Harmondsworth.

28. Salehi-Isfahani D and Dhillon N (2008), Stalled Youth Transitions in the Middle East: A Framework for Policy Reform, Middle East Youth Initiative Working Paper, Wolfensohn Centre for Development, Dubai.

29. Welzel C (2013), Freedom Rising: Human Empowerment and the Quest for Emancipation, Cambridge University Press, New York.

30. Welzel C, Inglehart R and Kingemann H-D (2003), 'The theory of human development: a cross-cultural analysis', European Journal of Political Research, 42, 341-379.

Талха Фадаак, Кен Робертс. Жінки, освіта і трудова зайнятість в Саудівській Аравії: приклад багатоликої сучасності

У даній роботі використовується офіційна статистика і попередні дослідження саудівських вчених, але в основному вона базується на даних, отриманих у результаті проведених авторами 23-х інтерв’ю протягом 2015 і 2016 років серед 25-35-річних чоловіків і жінок з метою розуміння модернізації в Саудівській Аравії, що включає в себе диверсифікацію економіки і активне поширення вищої освіти для чоловіків і жінок і яка є малообіцяючою для збільшення частки жінок у складі робочої сили. Цього можна очікувати, тому що загальна кількість робочих місць в країні навряд чи збільшиться, і можливості для жінок, швидше за все, залишуться обмеженими не тільки перевагами і практиками роботодавців під час найому, а й обмеженим діапазоном робочих місць, які молоді жінки і їх сім’ї вважають прийнятними. Таким чином, замість того, щоб слідувати тим же модернізаційним шляхом, що і західні суспільства, Саудівська Аравія радше стане ще одним прикладом багатоликої сучасності.

Ключові слова: освіта, трудова зайнятість, стать, пізній розвиток, модернізація, Саудівська Аравія.

Талха Фадаак, Кен Робертс. Женщины, образование и трудовая занятость в Саудовской Аравии: пример многоликой современности

В данной работе используется официальная статистика и предыдущие исследования саудовских ученых, но в основном она базируется на данных, полученных в результате проведенных авторами 23-х интервью в течение 2015 и 2016 годов среди 25-35-летних мужчин и женщин с целью понима- 
ния модернизации в Саудовской Аравии, включающей в себя диверсификацию экономики и широкое распространение высшего образования для мужчин и женщин и малообещающей увеличение доли женщин в составе рабочей силы. Этого можно ожидать, потому что общее количество рабочих мест в стране вряд ли увеличится, и возможности для женщин, скорее всего, останутся ограниченными не только предпочтениями и практиками работодателей при найме, но и диапазоном рабочих мест, которые молодые женщины и их семьи считают приемлемыми. Таким образом, вместо того, чтобы следовать тем же модернизационным путём, что и западные общества, Саудовская Аравия скорее станет еще одним примером многоликой современности.

Ключевые слова: образование, трудовая занятость, пол, позднее развитие, модернизация, Саудовская Аравия.

Talha Fadaak is Assistant Professor of Sociology at Umm al-Qura University, Jeddah. She graduated with a PhD from the University of Liverpool in 2011 with a thesis on Social Policies for the Eradication of Poverty among Female-Headed Households in Saudi Society. Her major research areas are poverty, social policy and development, and sociology of youth. She has published in English and Arabic language. Her book on Female Poverty in Saudi Arabia was published in 2012. In 2014 Dr Fadaak participated in a regional project that investigated social risks in Gulf Cooperation Countries. In 2015 she was the main coordinator for a project for Hail University that investigated Saudi women who are involved in social networks for preaching and other religious proposes. During 2015 and 2016 Dr Fadaak was visiting research fellow at Liverpool University.

E-mail: talha_fadak@hotmail.com

Ken Roberts is Professor of Sociology at University of Liverpool. His major research areas are the sociology of leisure, and the sociology of young people's life stage transitions. Since 1991 he has coordinated a series of research projects in East-Central Europe and the former Soviet Union. These have investigated how various social groups' circumstances have changed during the political and economic transformations of their countries. His current research is into young people in south and east Mediterranean countries during and since the Arab Spring of 2011. Professor Roberts' books include Surviving Post-Communism: Young People in the Former Soviet Union (2000), Youth in Eastern Europe and in the West (2009), Class in Contemporary Britain (2011), Sociology: An Introduction (2012), The Business of Leisure (2016), and Social Theory, Sport, Leisure (2016).

E-mail: bert@liverpool.ac.uk

Талха Фадаак - викладач соціології в Університеті Умм аль-Кура, Джидда. У 2011 році вона стала Доктором філософіï, захистивши в Ліверпуль- 
ському університеті дисертацію з питань соціальної політики та боротьби з бідністю серед домогосподарств, очолюваних жінками в саудівському суспільстві. Провідні сфери ії досліджень: бідність, соціальна політика і розвиток, соціологія молоді. Вона має публікації англійською та арабською мовами. Її книжка «Бідність серед жінок у Саудівській Аравії» надрукована у 2012 році. У 2014 році Доктор Фадаак взяла участь у регіональному проекті, присвяченому дослідженню соціальних ризиків у країнах, що входять до Ради з співробітництва арабських держав Персидської затоки. У 2015 році вона була головним координатором проекту в університеті Хейл, в якому досліджувались саудівські жінки, які беруть участь у соціальних мережах 3 релігійними цілями. Протягом 2015 і 2016 років Доктор Фадаак була запрошеним науковим співробітником у Ліверпульському університеті.

Кен Робертс - професор соціології Ліверпульського університету. Провідні напрямки його досліджень: соціологія дозвілля і соціологія перехідних життєвих етапів молоді. 31991 року він координував низку науково-дослідних проектів у Центральній і Східній Европі та колишнього Радянського Союзу. В них з'ясовувалось, як різні обставини соціальних груп змінилися під час політичних і економічних перетворень у цих країнах. На даний момент він досліджує молодь у південних і східних середземноморських країнах під час і після арабської весни 2011 року. Книги професора Робертса: «Виживаючий посткомунізм: молодь у колишньому Радянському Союзі» (2000), «Молодь у Східній Європі і на Заході» (2009), «Клас у сучасній Великобританії» (2011), «Соціологія: вступ» (2012), «Бізнес дозвілля» (2016 г.), «Соціальна теорія, спорт, дозвілля»(2016). 